\title{
Energy requirements and efficiency of energy utilization in growing dairy goats of different sexes
}

\author{
A. P. Souza, ${ }^{1,2}$ N. R. St-Pierre, ${ }^{3}$ M. H. M. R. Fernandes, ${ }^{1}$ A. K. Almeida, ${ }^{1,4}$ J. A. C. Vargas, ${ }^{1}$ K. T. Resende, ${ }^{1}$ \\ and I. A. M. A. Teixeira ${ }^{1 *}$ \\ ${ }^{1}$ Department of Animal Sciences, Universidade Estadual Paulista, Jaboticabal, SP 14884-900, Brazil \\ ${ }^{2}$ Instituto de Estudos do Trópico Úmido, Universidade Federal do Sul e Sudeste do Pará, Xinguara, PA 68557-335, Brazil \\ ${ }^{3}$ Department of Animal Sciences, The Ohio State University, Columbus 43201 \\ ${ }^{4}$ School of Environmental and Rural Science, University of New England, Armidale, NSW 2351, Australia
}

\begin{abstract}
The aim of this study was to investigate the effects of sex on the requirements for maintenance and efficiency of energy utilization in growing Saanen goats. A database from 7 comparative slaughter studies that included 238 Saanen goats was gathered to provide information for the development of prediction equations of energy requirements for maintenance and efficiency of energy utilization. The experimental design provided different levels of metabolizable energy intake (MEI) and empty body weight $(\mathrm{EBW})$. The data were analyzed so that sex (e.g., intact males, castrated males, and females; $n$ $=98,80$, and 60 , respectively) was a fixed effect, and blocks nested in the studies and goat sex were random effects. For the development of linear and nonlinear equations, we used the MIXED and NLMIXED procedures in SAS (SAS Institute Inc., Cary, NC). Nonlinear regression equations were developed to predict heat production (HP, $\mathrm{kcal} / \mathrm{kg}^{0.75}$ of EBW; dependent variable) from MEI ( $\mathrm{kcal} / \mathrm{kg}^{0.75}$ of EBW; independent variable). Using the comparative slaughter technique, the net energy requirement for maintenance $\left(\mathrm{NE}_{\mathrm{M}}\right)$ was calculated as the value of HP at MEI equal to zero. Additionally, $\mathrm{NE}_{\mathrm{M}}$ was evaluated based on the degree of maturity. The metabolizable energy requirement for maintenance was calculated as the value at which HP is equal to MEI. Efficiency of ME utilization for maintenance $\left(k_{m}\right)$ was calculated as the ratio between $\mathrm{NE}_{\mathrm{M}}$ and the metabolizable energy requirement for maintenance. Efficiency of energy utilization for growth $\left(k_{g}\right)$ was assumed to be the slope of the linear regression of retained energy (RE) on MEI above the maintenance stage (model intercept equal to 0). Efficiencies of RE
\end{abstract}

Received October 31, 2018.

Accepted August 29, 2019.

*Corresponding author: izabelle@fcav.unesp.br as protein $\left(\mathrm{k}_{\mathrm{p}}\right)$ and as fat $\left(\mathrm{k}_{\mathrm{f}}\right)$ were calculated using the multiple linear regression of MEI above the maintenance (model intercept equal to 0 ) on $\mathrm{RE}$ as protein and as fat, respectively. Sex affected $\mathrm{NE}_{\mathrm{M}}(75.0 \pm 1.76$ $\mathrm{kcal} / \mathrm{kg}^{0.75}$ of EBW for males and $63.6 \pm 2.89 \mathrm{kcal} /$ $\mathrm{kg}^{0.75}$ of EBW for females) and sex did not affect $\mathrm{k}_{\mathrm{m}}$ (0.63). In contrast, sex no longer affected $\mathrm{NE}_{\mathrm{M}}$ when degree of maturity was considered on its estimation. The $k_{g}$ was different between sexes ( 0.31 for castrated males and females, and 0.26 for intact males), but $\mathrm{k}_{\mathrm{p}}$ $(0.21)$ and $\mathrm{k}_{\mathrm{f}}(0.80)$ were similar between sexes. These results may be useful for improving robustness of the energy requirement recommendations for dairy goats.

Key words: comparative slaughter, degree of maturity, metabolizable energy, partitioning of energy

\section{INTRODUCTION}

The energy expenditure for tissue accretion and maintenance is different between the different tissues in the body (Gill et al., 1989). In this sense, we assume that the body composition of an animal is directly associated with its energy utilization. However, until now, evaluation of the effects of body composition on the requirements and efficiency of energy utilization with a large body composition data set had not been assessed in goats. The energy requirements for goats have mainly been obtained using calorimetric methods or feeding trials. A limitation of these methods is that they do not evaluate the direct effect of body composition on energy requirements (Sahlu et al., 2004; NRC, 2007; Salah et al., 2014).

Animal characteristics such as sex may affect the patterns of tissue deposition and consequently body energy. It has been reported that castrated males, intact males, and females differ in their body protein and fat content (Geay, 1984; Herring et al., 2013). For this reason, we would also expect that sex may affect goat energy requirements. Different feeding systems indicate that intact males require more $\mathrm{ME}_{\mathrm{M}}$ 
than females (ARC, 1980; CSIRO, 1990; NRC, 2000, 2007). Conversely, individual studies conducted with goats have generally concluded that sex affects energy requirements for growth, but it does not affect energy requirements for maintenance (Ash and Norton, 1987; Bompadre et al., 2014; Almeida et al., 2015; Figueiredo et al., 2017). Therefore, contradictory results have been reported.

To address the potential relationship between energy use and animal sex, we assembled a data set of the observations from individual animals included in 7 comparative slaughter studies and conducted a metaanalysis to investigate the effects of sex on the energy requirements for maintenance and on the efficiency of energy use in growing Saanen goats.

\section{MATERIALS AND METHODS}

\section{Data Collection}

A data set that included reference, qualifying (e.g., sex, level of intake, and block), and necessary quantitative data were gathered from 7 comparative slaughter studies (Gomes, 2011; Bompadre et al., 2014; Medeiros et al., 2014; Almeida et al., 2015; Ferreira et al., 2015; Figueiredo et al., 2016, 2017). Quantitative information included days on feed, initial and final BW, empty BW (EBW), DMI, metabolizable energy intake (MEI), and body composition for each individual animal. Body samples were analyzed for fat content (AOAC, 1990, method 930.15), protein content by $\mathrm{N}$ analysis with Dumas combustion using Leco FP-528LC (Etheridge et al., 1998), and energy content using an adiabatic calorimetric bomb following protocols described in each of the studies used for data set construction (Table 1).

All procedures used in the individual studies were performed in accordance with the Animal Care Committee (Comissão de Ética e Bem-Estar Animal) of the Universidade Estadual Paulista. During the experiments, mean daily minimum and maximum temperatures were 16.3 and $35.7^{\circ} \mathrm{C}$, respectively, and minimum and maximum relative humidity of the air were 21.5 and $88.6 \%$, respectively.

The goats used across the studies were randomly allocated to 1 of 3 levels of feed restriction (i.e., composing blocks): $0 \%$ of feed restriction (ad libitum), approximately $25 \%$ of feed restriction, or $50 \%$ of feed restriction based on ad libitum feed intake. Each block included 3 goats of the same sex and with similar BW.

The goats were housed in individual metabolic cages for evaluating the ME concentration of the diets. Feed intake and feed refusals were recorded; feces and urine were collected for $5 \mathrm{~d}$ after the adaptation period. The collected urine was acidified daily with $20 \mathrm{~mL}$ of $6 \mathrm{M}$
$\mathrm{HCl}$. The offered feed and feed refusals were sampled daily, and samples were stored at $-20^{\circ} \mathrm{C}$. Feces and urine were weighed daily and a $10 \%$ total output sample was stored at $-20^{\circ} \mathrm{C}$. Composites of the feed, feed refusals, and feces were dried at 60 to $65^{\circ} \mathrm{C}$ for 72 $\mathrm{h}$ and ground through a 1-mm screen using a Wiley mill. These samples were analyzed for protein content by $\mathrm{N}$ analysis performed via Dumas and energy content was measured using an adiabatic calorimetric bomb described by the protocols referenced above for body samples.

Table 1. Summary of descriptive statistics for body composition in Saanen goats used in this study

\begin{tabular}{|c|c|c|c|c|}
\hline Variable & $\mathrm{n}^{1}$ & Mean & $\mathrm{SD}$ & Range \\
\hline \multicolumn{5}{|l|}{$\mathrm{EBW},{ }^{2} \mathrm{~kg}$} \\
\hline All animals & 238 & 22.3 & 9.83 & 4.1 to 41.7 \\
\hline Castrated male & 80 & 22.2 & 8.56 & 4.1 to 39.7 \\
\hline Intact male & 98 & 21.3 & 10.6 & 5.1 to 41.7 \\
\hline Female & 60 & 24.2 & 9.94 & 6.6 to 40.4 \\
\hline \multicolumn{5}{|l|}{$\mathrm{ADG}, \mathrm{g} / \mathrm{d}$} \\
\hline All animals & 238 & 96.6 & 64.1 & -18.8 to 264 \\
\hline Castrated male & 80 & 95.0 & 68.4 & -16.8 to 259 \\
\hline Intact male & 98 & 111.4 & 64.5 & -13.6 to 264 \\
\hline Female & 60 & 74.4 & 50.2 & -18.8 to 186 \\
\hline \multicolumn{5}{|l|}{$\mathrm{EWG},{ }^{3} \mathrm{~g} / \mathrm{d}$} \\
\hline All animals & 238 & 82.5 & 54.2 & -16.0 to 239 \\
\hline Castrated male & 80 & 83.8 & 60.5 & -8.7 to 239 \\
\hline Intact male & 98 & 90.6 & 53.1 & -16.0 to 219 \\
\hline Female & 60 & 67.5 & 43.8 & -10.3 to 171 \\
\hline \multicolumn{5}{|l|}{ DMI, g/d } \\
\hline All animals & 238 & 600 & 332 & 104 to 1,528 \\
\hline Castrated male & 80 & 681 & 343 & 128 to 1,440 \\
\hline Intact male & 98 & 535 & 335 & 104 to 1,528 \\
\hline Female & 60 & 600 & 290 & 130 to 1,287 \\
\hline \multicolumn{5}{|l|}{ ME intake, $\mathrm{kcal} / \mathrm{d}$} \\
\hline All animals & 238 & 1,603 & 690 & 415 to 3,272 \\
\hline Castrated male & 80 & 1,729 & 706 & 484 to 3,272 \\
\hline Intact male & 98 & 1,503 & 700 & 415 to 3,218 \\
\hline Female & 60 & 1,598 & 632 & 525 to 2,895 \\
\hline \multicolumn{5}{|l|}{$\mathrm{RE},{ }^{4} \mathrm{kcal} / \mathrm{d}$} \\
\hline All animals & 238 & 261 & 212 & -83 to 1,061 \\
\hline Castrated male & 80 & 291 & 237 & -76 to 1,061 \\
\hline Intact male & 98 & 227 & 181 & -83 to 930 \\
\hline Female & 60 & 274 & 215 & -83 to 853 \\
\hline \multicolumn{5}{|l|}{$\mathrm{RE}_{\mathrm{p}}{ }^{5} \mathrm{kcal} / \mathrm{d}$} \\
\hline All animals & 238 & 84.5 & 62.6 & -71.8 to 302 \\
\hline Castrated male & 80 & 91.6 & 68.7 & -21.6 to 289 \\
\hline Intact male & 98 & 93.1 & 62.9 & -71.8 to 302 \\
\hline Female & 60 & 60.9 & 46.1 & -38.7 to 164 \\
\hline \multicolumn{5}{|l|}{$\mathrm{RE}_{\mathrm{f}}{ }^{6}{ }^{6} \mathrm{kcal} / \mathrm{d}$} \\
\hline All animals & 238 & 197 & 180 & -133 to 802 \\
\hline Castrated male & 80 & 220 & 194 & -133 to 717 \\
\hline Intact male & 98 & 148 & 148 & -54.9 to 802 \\
\hline Female & 60 & 245 & 193 & -40.5 to 783 \\
\hline
\end{tabular}

${ }^{1}$ Number of records used.

${ }^{2}$ Slaughter empty BW.

${ }^{3} \mathrm{EWG}=$ empty weight gain.

${ }^{4} \mathrm{RE}=$ retained energy. The measurements of energy were obtained using a bomb calorimeter.

${ }^{5} \mathrm{RE}_{\mathrm{p}}=\mathrm{RE}$ as protein.

${ }^{6} \mathrm{RE}_{\mathrm{f}}=\mathrm{RE}$ as fat. 


\section{Data Calculation and Analyses}

Prediction of MEI. The MEI was calculated based on the ME concentration of the diet fed to goats (kcal/ $\mathrm{kg}$ of $\mathrm{DM}$ ) that was estimated from GE intake, total energy losses from feces, urine, and gaseous products of digestion. Fecal and urinary excretions were obtained from their total collection. Energy loss from gaseous products of digestion was predicted according to Blaxter and Clapperton (1965). The ratios between DE and gross energy (GE) variables (DE:GE), between ME and GE variables ( $\boldsymbol{q}$, or metabolizability), as well as between $\mathrm{ME}$ and DE variables (ME:DE), were evaluated. Values of predicted ME concentration for animals that were not part of the digestibility trials were derived from a linear model that predicted the ME concentration of the diet from DMI obtained during the experiment. The mixed model used in the meta-analysis included blocks (i.e., each block consisted of 3 goats submitted to each level of feed restriction) nested within study and sex [block (study $\times$ sex)] as the random effect, and sex as a fixed effect.

Energy Requirements. The $\mathrm{NE}_{\mathrm{M}}$ was estimated using the comparative slaughter technique previously described by Lofgreen and Garrett (1968). The initial body energy was calculated as follows: (1) initial EBW of the animals was predicted from initial BW, and (2) initial body energy was predicted from initial EBW with allometric equations across all trials, according to the equations reported by Souza et al. (2017).

Daily heat production ( $\mathbf{H P}, \mathrm{kcal} / \mathrm{kg}^{0.75}$ of EBW) was calculated as the difference between daily MEI (kcal/ $\mathrm{kg}^{0.75}$ of EBW) and daily RE (kcal $/ \mathrm{kg}^{0.75}$ of EBW). The $\mathrm{NE}_{\mathrm{M}}$ was estimated as the value of $\mathrm{HP}$ at MEI that was equal to zero, and $\mathrm{ME}$ for maintenance $\left(\mathbf{M E}_{\mathbf{M}}\right)$ was the value when MEI was equal to HP. The relationship between HP and MEI was modeled as a nonlinear mixed model as follows:

$$
Y_{i j k l}=\mathrm{B}_{0 i} \times \exp \left(\mathrm{B}_{1 i} \times X_{i j k l}\right)+s_{j}+z_{k(j)}+e_{i j k l},
$$

where $Y_{i j k l}$ is the HP $\left(\mathrm{kcal} / \mathrm{kg}^{0.75}\right.$ of EBW) for the $l$ th animal of the $i$ th sex in the $j$ th study in the $k$ th block, $X_{i j k l}$ is the daily MEI ( $\mathrm{kcal} / \mathrm{kg}^{0.75}$ of EBW) for the $l \mathrm{th}$ animal of the $i$ th sex in the $j$ th study in the $k$ th block, $\mathrm{B}_{0 i}$ and $\mathrm{B}_{1 i}$ are parameters estimated for each of the $i=$ $1,2,3$ sexes, $s_{j}$ is the random effect of the $j$ th study $\sim N\left(\mathbf{0}, \sigma_{s}^{2}\right)$, where $\sigma_{s}^{2}$ is the study variance, $z_{k(j)}$ is the effect of the $k$ th block nested in the $j$ th study, and $e_{i j k l}$ is the residual error $\sim N\left(\mathbf{0}, \sigma_{e}^{2}\right)$, where $\sigma_{e}^{2}$ is the residual variance.

The inclusion of the degree of maturity in the model was evaluated applying similar approach used by
Freetly et al. (2002), evaluating the nonlinear relationship between HP and ratio $\mathrm{BW} /$ mature EBW. This approach was modified and scaled by EBW using the daily HP (kcal $/ \mathrm{kg}$ of EBW) regressed against the ratio $\mathrm{EBW} /$ mature EBW. We adopted the mature EBW of Saanen goats reported by Almeida et al. (2016), that is $34.9,42.6$, and $26.0 \mathrm{~kg}$ of EBW for castrated males, intact males, and females, respectively. For this approach, we only included data from goats up to the ratio EBW/mature EBW equal 1 (98 intact males, 72 castrated males, and 36 females), because our database only had data from goats greater than 1 for females and castrated males.

The approach proposed by Luo et al. (2004), based on feeding trials, was also used to estimate $\mathrm{ME}_{\mathrm{M}}$. The animals used in our analyses were the same animals presented in the data set used in the comparative slaughter technique. The MEI (kcal $/ \mathrm{kg}^{0.75}$ of BW) was regressed against $\mathrm{ADG}\left(\mathrm{g} / \mathrm{kg}^{0.75}\right.$ of BW). This approach was modified and scaled by EBW using the daily MEI ( $\mathrm{kcal} / \mathrm{kg}^{0.75}$ of EBW) regressed against empty BW gain (EWG; $/ \mathrm{kg}^{0.75}$ of EBW). In addition to the regression analyses that provided estimates of the $\mathrm{ME}_{\mathrm{M}}$, the $\mathrm{ME}$ for gain $\left(\mathbf{M E}_{\mathbf{G}}\right)$ was estimated as the slope of the linear regression of daily MEI ( $\mathrm{kcal} / \mathrm{kg}^{0.75}$ of EBW) against EWG $\left(\mathrm{g} / \mathrm{kg}^{0.75}\right.$ of EBW).

Efficiencies of ME Utilization. Using data from the comparative slaughter technique, efficiency of $\mathrm{ME}$ utilization for maintenance $\left(\mathbf{k}_{\mathbf{m}}\right)$ was estimated as the ratio between $\mathrm{NE}_{\mathrm{M}}$ and $\mathrm{ME}_{\mathrm{M}}$.

Partial efficiency of ME utilization for growth $\left(\mathbf{k}_{\mathrm{g}}\right)$ was assumed to be the slope of the linear regression of $\mathrm{RE}$ on MEI above maintenance $\left(\mathbf{M E I}_{\mathrm{G}}\right)=\mathrm{MEI}-$ $\mathrm{ME}_{\mathrm{M}}$, assuming that $\mathrm{RE}$ is null when $\mathrm{MEI}_{\mathrm{G}}=0$ (i.e., model intercept $=0$ ) according to Galvani et al. (2014).

Efficiencies of RE both as protein $\left(\mathbf{k}_{\mathbf{p}}\right)$ and fat $\left(\mathbf{k}_{\mathbf{f}}\right)$ were calculated using the multiple linear regression of $\mathrm{MEI}_{\mathrm{G}}$ (Equation [2]), where RE as protein $\left(\mathbf{R E}_{\mathbf{p}}\right)$ and fat $\left(\mathbf{R E}_{\mathbf{f}}\right)$ were calculated as the difference between the final and initial BW of the respective body protein or fat multiplied by the energetic values of protein (5.585 $\mathrm{kcal} / \mathrm{g})$ or fat $(9.367 \mathrm{kcal} / \mathrm{g})$. The partitioning of MEI to $\mathrm{RE}_{\mathrm{p}}$ and $\mathrm{RE}_{\mathrm{f}}$ was computed using a multiple regression as follows:

$$
Y_{i j k l}=b_{1 \mathrm{i}} \times \mathrm{RE}_{\mathrm{p}}+b_{2 i} \times \mathrm{RE}_{\mathrm{f}}+s_{j}+z_{k(j)}+e_{i j k l},[2]
$$

where $Y_{i j k l}$ is the $\mathrm{MEI}_{\mathrm{G}}\left(\mathrm{kcal} / \mathrm{kg}^{0.75}\right.$ of EBW) for the $l$ th animal of the $i$ th sex in the $j$ th study in the $k$ th block, $\mathrm{RE}_{\mathrm{p}}$ and $\mathrm{RE}_{\mathrm{f}}$ are the $\mathrm{RE}\left(\mathrm{kcal} / \mathrm{kg}^{0.75}\right.$ of EBW) as protein and as fat, respectively, $b_{1 i}$ and $b_{2 i}$ are parameters to be estimated for each of the $i=1,2,3$ sexes, $s_{j}$ is the random effect of the $j$ th study $\sim N\left(\mathbf{0}, \sigma_{s}^{2}\right), z_{k(j)}$ is the ef- 
fect of the $k$ th block nested in the $j$ th study, and $e_{i j k l}$ is the residual error $\sim N\left(\mathbf{0}, \sigma_{e}^{2}\right)$.

The $\mathrm{k}_{\mathrm{p}}$ and $\mathrm{k}_{\mathrm{f}}$ were calculated as the inverse of the parameter estimates $b_{1}$ and $b_{2}$, respectively.

\section{Statistical Analysis}

Statistical analysis was performed using SAS (version 9.4, SAS Institute Inc., Cary, NC). The linear regression analyses were computed using the MIXED procedure. Statistical models included blocks and studies as random effects, as well as sex (i.e., castrated male, intact male, and female) as fixed effects. When sex was significant $(P<0.10)$, indicated as a different intercept for at least one sex, 3 contrast statements were used to conduct all 3 pairwise comparisons of sex. Likewise, 3 contrast statements were used to conduct all 3 pairwise comparisons when the interaction between sex and regressor effects was significant $(P<0.10)$, which indicated that at least one sex had a different slope. Outliers were removed when their normalized residuals were $>|3|$.

The NLMIXED procedure was used to fit nonlinear models. The statistical models included sex (i.e., castrated male, intact male, and female) as fixed effects and nested block designs for study and sex as random effects. We used a dummy variable approach to assess sex effects on the regression parameters. In other words, 3 dummy variables (a1, a2, and a3) were created for castrated males, $\mathrm{a} 1=1, \mathrm{a} 2=0$, and $\mathrm{a} 3=0$; for intact males, $\mathrm{a} 1=0, \mathrm{a} 2=1$, and $\mathrm{a} 3=0$; and for females, $\mathrm{a} 1$ $=0, \mathrm{a} 2=0$, and $\mathrm{a} 3=1$. CONTRAST statements were used for testing whether a regression parameter differed across the 3 sexes.

A Monte Carlo-based simulation was used to calculate numerical estimates of variance and confidence intervals for both energy requirements and efficiencies of energy utilization. Simulated values were generated using a multivariate normal distribution for parameter estimates using the algorithm of Fan et al. (2002).

\section{RESULTS}

\section{Estimation of MEI}

Sex affected the DE:GE ratio $(P=0.048)$, where females presented greater DE:GE than intact males $(0.74$ vs. $0.71 ; P=0.01)$ and castrated males ( 0.74 vs. 0.72 ; $P=0.09)$, whereas DE:GE was similar between intact males and castrated males $(0.72 ; P=0.48)$. However, sex did not affect the ME:DE $(0.83 ; P=0.47)$ and ME:GE $(0.60 ; P=0.16)$ in the digestibility trial (Table 2).

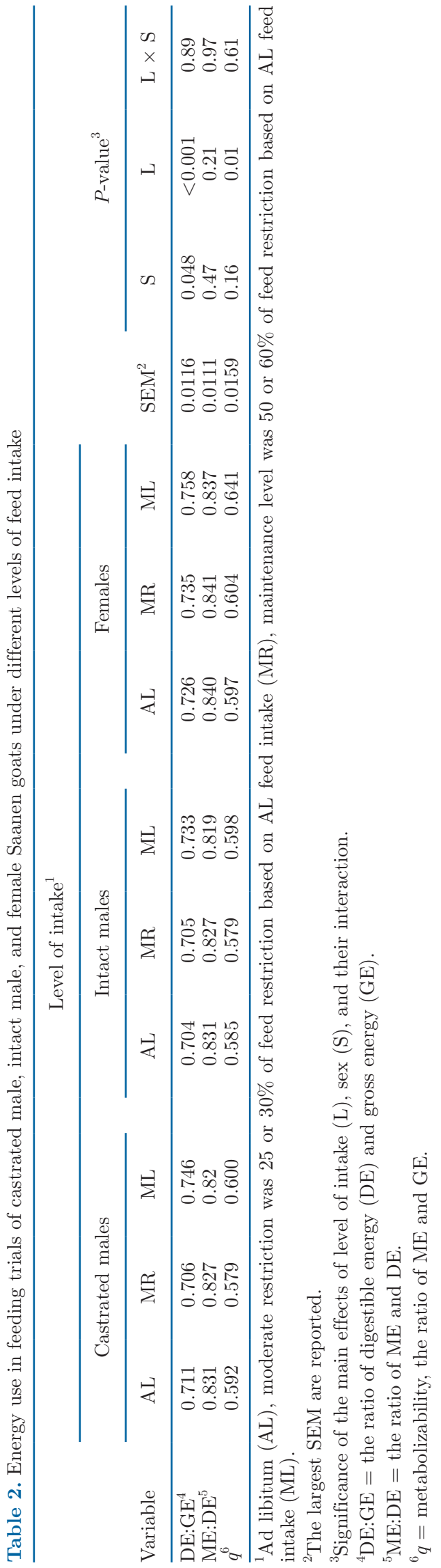


Level of intake affected the DE:GE ratio $(P<0.001$; Table 2), where animals fed at the maintenance level presented a greater DE:GE $(0.75 ; P<0.001)$ than animals fed at the moderate feed restriction $(0.71)$ or ad libitum (0.71), whereas DE:GE was similar between animals fed at moderate restriction and ad libitum $(P=0.80)$. Additionally, the ME:GE ratio was also greater in animals fed at the maintenance level than in those fed at moderate restriction (0.61 vs. $0.59 ; P=$ $0.005)$ and ad libitum (0.61 vs. $0.59 ; P=0.01$ ), whereas ME:GE was similar between animals fed at moderate restriction and ad libitum $(0.59 ; P=0.68)$. We did not detect any effect of the level of intake on the ME:DE ratio $(0.83 ; P=0.21)$.

Values of predicted ME concentrations (kcal $/ \mathrm{kg}$ of DM) for animals that were not part of the digestibility experiment were derived from the model presented in Equation [3]. The model was obtained using data of both ME concentration (kcal/ $\mathrm{kg}$ of DM) and daily DMI $\left(\mathrm{g} / \mathrm{kg}^{0.75}\right.$ of $\left.\mathrm{BW}\right)$. The parameters did not differ between sexes $(P>0.10)$ and the fitted equation was as follows $\left(\mathrm{n}=206, \sigma_{s}^{2}=50,612, \sigma_{e}^{2}=82,791\right)$, where for all sexes,

$$
\mathrm{ME}=2,919.5( \pm 102)-5.14( \pm 1.33) \times \text { DMI }
$$

\section{Energy Requirements}

The nonlinear regression indicated that HP exponentially increased as MEI increased (Figure 1). Sex affected parameter estimates of the equations presented in Table 3. Parameters $B_{0}(P=0.75)$ and $B_{1}(P=0.51)$ were similar between castrated and intact males; however, $B_{0}(P=0.003)$ and $B_{1}(P=0.01)$ were different between both male groups and females, $B_{0}(P=0.003)$ and $B_{1}(P=0.03)$. Therefore, we applied parameters to each sex and one general equation to all males because castrated and intact males were similar in this respect (Table 3). The $\mathrm{NE}_{\mathrm{M}}$ (i.e., value of $\mathrm{HP}$ when MEI was equal to zero) was estimated to be $75.0 \pm 1.76 \mathrm{kcal} /$ $\mathrm{kg}^{0.75}$ of EBW for males; this value was $16 \%$ greater than the $\mathrm{NE}_{\mathrm{M}}$ obtained for females $(63.6 \pm 2.89 \mathrm{kcal} /$ $\mathrm{kg}^{0.75}$ of EBW) as well as observed to $\mathrm{ME}_{\mathrm{M}}$ (120.9 vs. $101.2 \mathrm{kcal} / \mathrm{kg}^{0.75}$ of EBW; Table 3).

When we evaluated the relationship between HP (kcal/kg of EBW) and ratio EBW/mature EBW (Figure 2), the parameters $B_{0}$ and $B_{1}$ did not differ between castrated males, intact males, and females $(P>0.01)$. Therefore, we reported one equation for all sexes (Equation $\left.[4] ; \mathrm{n}=203 ; \sigma_{b: s}^{2}=1.76, \sigma_{e}^{2}=169.1\right)$ :

$$
\begin{aligned}
\mathrm{HP}= & 95.2( \pm 3.78) \times \exp [-0.621( \pm 0.0647) \\
& \times \text { ratio } \mathrm{EBW} / \text { mature } \mathrm{EBW}]
\end{aligned}
$$

where HP was the daily HP (kcal/kg of EBW).

Considering the same parameters, the $\mathrm{NE}_{\mathrm{M}}$ values obtained from the nonlinear approach considering degree of maturity were similar between sexes at 5 degrees of maturity (i.e., 0.2, 0.4, 0.6, 0.8, and 1.0).

Using the approach suggested by Luo et al. (2004), we developed a relationship between ADG $\left(\mathrm{g} / \mathrm{kg}^{0.75}\right.$ of $\mathrm{BW})$ and MEI (kcal $/ \mathrm{kg}^{0.75}$ of BW) (Equation [5]; $\mathrm{n}=$ $\left.235, \sigma_{b: s}^{2}=214.0, \sigma_{e}^{2}=753.4\right)$ for Saanen goats:

$$
\begin{gathered}
\text { all sexes: } \mathrm{MEI}=111.6( \pm 3.72) \\
+12.5( \pm 0.732) \times \mathrm{ADG}
\end{gathered}
$$

where MEI is the daily MEI ( $\mathrm{kcal} / \mathrm{kg}^{0.75}$ of $\left.\mathrm{BW}\right)$ and ADG is expressed in $\mathrm{g} / \mathrm{kg}^{0.75}$ of BW.

The $\mathrm{ME}_{\mathrm{M}}$ did not differ between sexes $(P=0.28)$; the overall value for $\mathrm{ME}_{\mathrm{M}}$ was $111.6( \pm 3.72) \mathrm{kcal} / \mathrm{kg}^{0.75}$ of $\mathrm{BW}$, whereas the overall value for $\mathrm{ME}_{\mathrm{G}}$ was $12.5 \mathrm{kcal} / \mathrm{g}$ of ADG. When the same approach (Luo et al., 2004) was scaled by EBW, the estimated $\mathrm{ME}_{\mathrm{M}}$ was $(126.2 \pm$ 3.89 ) $\mathrm{kcal} / \mathrm{kg}^{0.75}$ of EBW (Figure 3) and no differences were observed between the parameter estimates in the different sexes $(P=0.56)$. Using the same approach, $\mathrm{ME}_{\mathrm{G}}$ was assumed to be the slope of the linear regression and, therefore, the estimated $\mathrm{ME}_{\mathrm{G}}$ was $15.0 \mathrm{kcal} / \mathrm{g}$ of EWG.

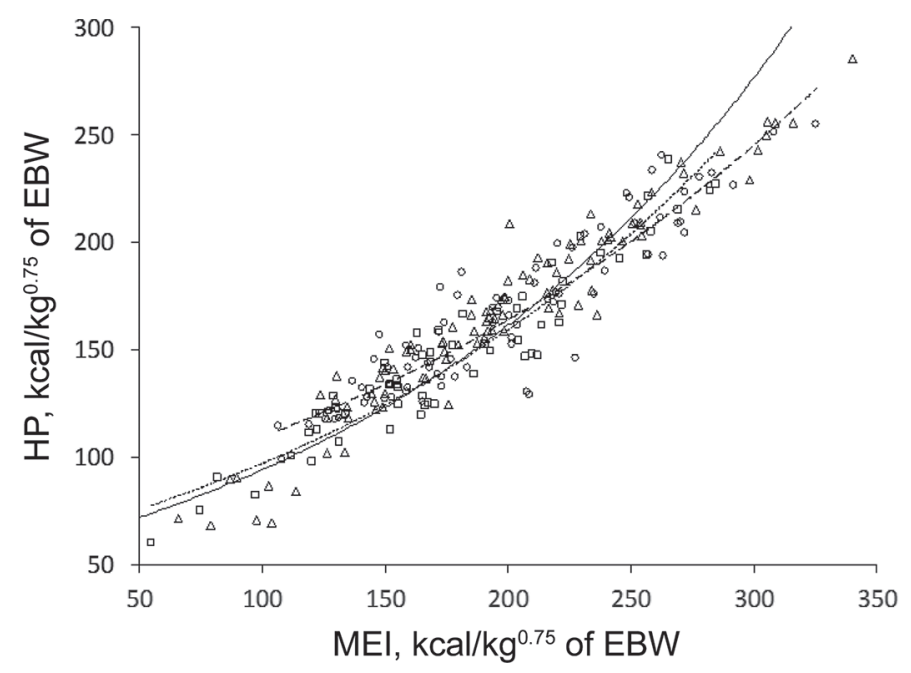

Figure 1. Relationship between heat production $\left[\mathrm{HP} ; \mathrm{kcal} / \mathrm{kg}^{0.75}\right.$ of empty BW (EBW)] and ME intake (MEI; kcal $/ \mathrm{kg}^{0.75}$ of EBW) in Saanen goats of different sexes $[\bigcirc$ castrated males (dashed line), $\Delta$ intact males (continuous line), and $\square$ females (dotted line)]: males HP $=75.0( \pm 1.76) \times \exp [0.00395( \pm 0.000104) \times$ MEI $]$; females HP $=$ $63.6( \pm 2.89) \times \exp [0.00458( \pm 0.000221) \times \mathrm{MEI}]$. The estimated study variances $\left(\sigma_{b: s}^{2}\right)$ and the residual variances $\left(\sigma_{e}^{2}\right)$ were 4.84 and 144.1, respectively. The parameters of the equation differed between males and females $(P<0.01)$, but they did not differ between castrated males and intact males $(P>0.10)$. 
Table 3. Parameter estimates of the regression equations for heat production (HP, $\mathrm{kcal} / \mathrm{kg}^{0.75}$ of empty BW) according to ME intake (MEI, $\mathrm{kcal} / \mathrm{kg}^{0.75}$ of empty BW) used to estimate energy requirements for maintenance by sex on Saanen goats ${ }^{1}$

\begin{tabular}{|c|c|c|c|c|c|c|c|c|c|}
\hline \multirow[b]{2}{*}{ Sex } & \multirow[b]{2}{*}{$\mathrm{n}^{2}$} & \multirow[b]{2}{*}{$B_{0} \pm \mathrm{SE}$} & \multirow[b]{2}{*}{$B_{1} \pm \mathrm{SE}$} & \multicolumn{3}{|c|}{$\mathrm{ME}_{\mathrm{M}}$} & \multicolumn{3}{|c|}{$\mathrm{k}_{\mathrm{m}}{ }^{3}$} \\
\hline & & & & Mean & $\mathrm{LCI}^{4}$ & $\mathrm{UCI}^{5}$ & Mean & LCI & UCI \\
\hline Intact male & 94 & $74.4 \pm 2.20$ & $0.00402 \pm 0.000126$ & 121.0 & 114.2 & 127.2 & 0.62 & 0.60 & 0.62 \\
\hline Female & 60 & $63.6 \pm 2.89$ & $0.00459 \pm 0.000221$ & 101.2 & 92.3 & 108.8 & 0.63 & 0.62 & 0.64 \\
\hline All males ${ }^{6}$ & 174 & $75.0 \pm 1.76$ & $0.00395 \pm 0.000104$ & 120.9 & 115.7 & 125.5 & 0.62 & 0.61 & 0.63 \\
\hline
\end{tabular}

${ }^{1}$ Model: $\mathrm{HP}=B_{0} \times \exp \left(B_{1} \times \mathrm{MEI}\right)$. The parameters $B_{0}$ and $B_{1}$ did not differ between castrated males and intact males $(P>0.10)$. The NE was calculated as the value assuming MEI equals zero (value of parameter $B_{0}$ ). The ME for maintenance $\left(\mathrm{ME}_{\mathrm{M}}\right)$ was calculated by iteration assuming $\mathrm{HP}$ is equal to MEI at maintenance. The estimated study variances and residual variances were $\sigma_{b: s}^{2}=4.148$ and $\sigma_{e}^{2}=144.1$, respectively.

${ }^{2}$ Total number of animals used to estimate parameters.

${ }^{3}$ The efficiency of use of $\mathrm{ME}$ for $\mathrm{NE}_{\mathrm{M}}$ was calculated as $\mathrm{NE}_{\mathrm{M}} / \mathrm{ME}_{\mathrm{M}}$.

${ }^{4} \mathrm{LCI}=$ lower $90 \%$ confidence limit of requirement.

${ }^{5} \mathrm{UCI}=$ upper $90 \%$ confidence limit of requirement.

${ }^{6}$ Pooled castrated males and intact males.

Taken together, these results indicate that the approach used (comparative slaughter technique or feeding trials) provided differences about the effect of sex on the values of energy requirements for maintenance in this meta-analysis.

\section{Efficiencies of ME Utilization}

The $\mathrm{k}_{\mathrm{m}}$ values were estimated as the ratio between $\mathrm{NE}_{\mathrm{M}}$ and $\mathrm{ME}_{\mathrm{M}}$, which did not differ between sexes, and ranged from 0.62 to 0.64 in females and 0.61 to 0.63 in males (Table 3 ).

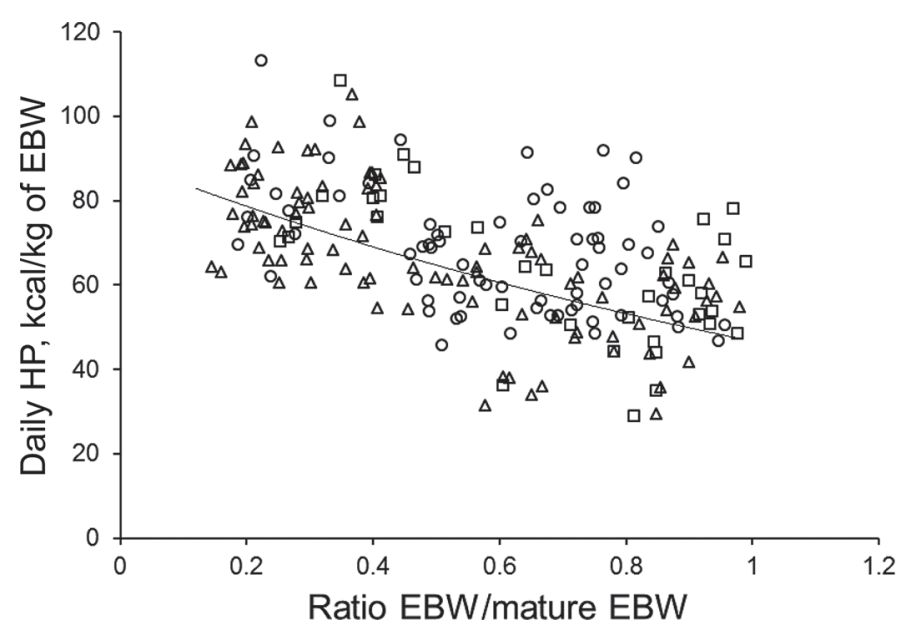

Figure 2. Daily heat production [HP; kcal $/ \mathrm{kg}$ of empty BW $(\mathrm{EBW})]$ as a function of the ratio EBW/mature EBW of Saanen goats ( $\bigcirc$ castrated males, $\Delta$ intact males, and $\square$ females). For all animals, $\mathrm{HP}=95.2( \pm 3.78) \times \exp [-0.621( \pm 0.0647) \times$ ratio EBW/mature EBW]. The estimated study variances $\left(\sigma_{b: s}^{2}\right)$ and the residual variances $\left(\sigma_{e}^{2}\right)$ were 1.76 and 169.1 , respectively. The parameters of the equation did not differ between sexes $(P>0.10)$.
The $\mathrm{k}_{\mathrm{g}}$ for each sex was estimated using the regression equations for $\mathrm{MEI}_{\mathrm{G}}$ on RE (Equations [6], [7], and $\left.[8] ; \mathrm{n}=230 ; \sigma_{b: s}^{2}=37.8, \sigma_{e}^{2}=90.9\right)$ :

castrated males: $\mathrm{RE}=0.320( \pm 0.0237) \times \mathrm{MEI}_{\mathrm{G}},[6]$

$$
\text { intact males: } \mathrm{RE}=0.260( \pm 0.0195) \times \mathrm{MEI}_{\mathrm{G}}, \quad[7]
$$

$$
\text { females: } \mathrm{RE}=0.310( \pm 0.0279) \times \mathrm{MEI}_{\mathrm{G}} \text {, }
$$

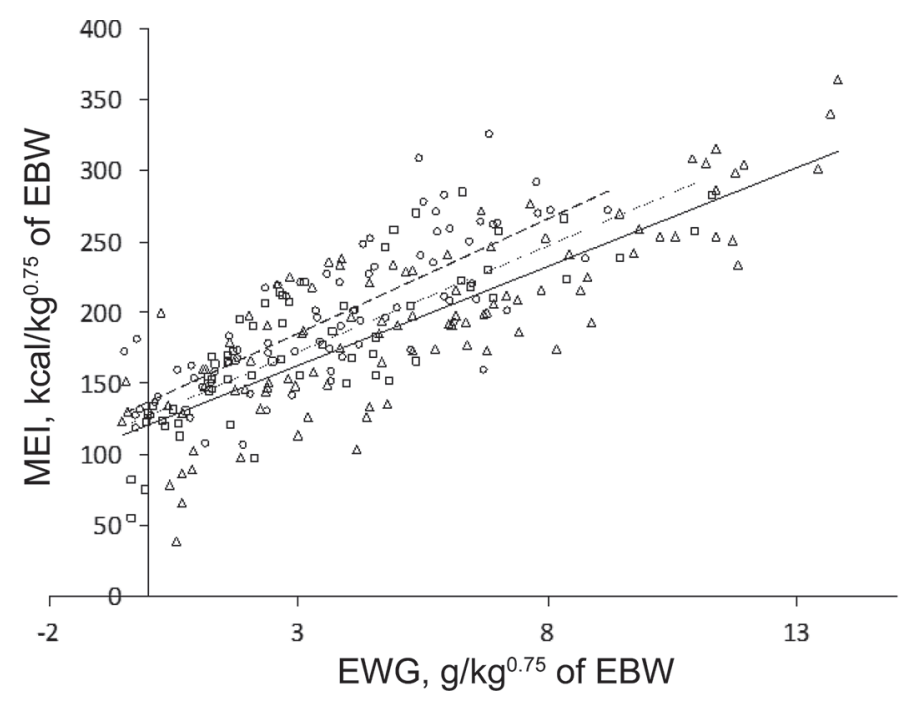

Figure 3. Relationship between empty weight gain $\left[\mathrm{EWG} ; \mathrm{g} / \mathrm{kg}^{0.75}\right.$ of empty BW (EBW)] and ME intake (MEI; kcal $/ \mathrm{kg}^{0.75}$ of EBW) of Saanen goats $[\bigcirc$ castrated males (dashed line), $\Delta$ intact males (continuous line), and $\square$ females (dotted line)]. For all animals MEI $=$ $126.2( \pm 3.89)+15.7( \pm 0.801) \times$ EWG. The estimated study variances $\left(\sigma_{b: s}^{2}\right)$ and the residual variances $\left(\sigma_{e}^{2}\right)$ were 112.7 and 959.2 , respectively. The parameters of the equation did not differ between sexes $(P>0.10)$. 
Table 4. Regression of retained energy $(\mathrm{RE})$ as fat and protein on ME intake above maintenance $\left(\mathrm{MEI}_{\mathrm{G}}\right)$ to estimate the partial efficiency of energy retention as fat and as protein in Saanen goats ${ }^{1}$

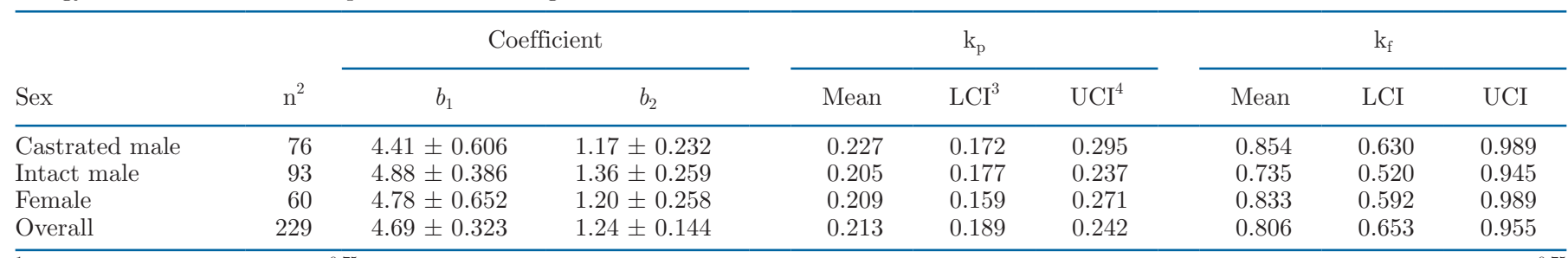

${ }^{1}$ Model: daily $\mathrm{MEI}_{\mathrm{G}}\left(\mathrm{kcal} / \mathrm{kg}^{0.75}\right.$ of empty $\left.\mathrm{BW}\right)=b_{1} \mathrm{RE}_{\mathrm{p}}+b_{2} \mathrm{RE}_{\mathrm{f}}$, where $\mathrm{RE}_{\mathrm{p}}$ and $\mathrm{RE}_{\mathrm{f}}=$ daily $\mathrm{RE}$ as protein and fat, respectively $\left(\mathrm{kcal} / \mathrm{kg}^{0.75}\right.$ of empty BW). The parameters $b_{1}$ and $b_{2}$ did not differ between sexes $(P>0.10)$. The efficiencies of $\mathrm{RE}$ as protein and fat $\left(\mathrm{k}_{\mathrm{p}}\right.$ and $\left.\mathrm{k}_{\mathrm{f}}\right)$ were calculated as $1 / b_{1}$ and $1 / b_{2}$, respectively.

${ }^{2}$ Total number of animals used to estimate the parameters.

${ }^{3} \mathrm{LCI}=$ lower $90 \%$ confidence limit of requirement.

${ }^{4} \mathrm{UCI}=$ upper $90 \%$ confidence limit of requirement.

where RE was the daily RE (kcal/ $\mathrm{kg}^{0.75}$ of $\left.\mathrm{EBW}\right)$ and $\mathrm{MEI}_{\mathrm{G}}$ was the daily MEI above maintenance (kcal/ $\mathrm{kg}^{0.75}$ of EBW).

The slope was assumed to be the $\mathrm{k}_{\mathrm{g}}$ and it did not differ between intact males and females $(P=0.14)$. However, the slope calculated for castrated males was greater than for intact males $(P=0.055)$ but it did not differ from that for females $(P=0.79)$. Therefore, we reported applicable parameters for each sex where the values of $\mathrm{k}_{\mathrm{g}}$ for castrated males, intact males, and females were $0.32,0.26$, and 0.31 , respectively.

In addition, to investigate sex effects on $\mathrm{k}_{\mathrm{p}}$ and $\mathrm{k}_{\mathrm{f}}$, we developed a multiple regression of the partitioning of MEI to $\mathrm{RE}_{\mathrm{p}}$ and $\mathrm{RE}_{\mathrm{f}}$ (Table 4$)$. Sex did not affect $\mathrm{k}_{\mathrm{p}}(P$ $=0.80)$ and $\mathrm{k}_{\mathrm{f}}(P=0.84)$, and the overall value of $\mathrm{k}_{\mathrm{p}}$ (0.21) was lower than the value for $\mathrm{k}_{\mathrm{f}}(0.80$; Table 4$)$. The uncertainty in the estimates for $\mathrm{k}_{\mathrm{f}}$ was noticeably greater than in the values for $\mathrm{k}_{\mathrm{p}}$.

\section{DISCUSSION}

Sex effects on energy requirements and the efficiency of energy utilization were evaluated in Saanen goats. We found that sex affects both $\mathrm{NE}_{\mathrm{M}}$ and $\mathrm{ME}_{\mathrm{M}}$ estimated using a comparative slaughter technique. Conversely, sex did not affect $\mathrm{ME}_{\mathrm{M}}$ and $\mathrm{ME}_{\mathrm{G}}$ estimated by feeding trials. In addition, sex did not affect $\mathrm{k}_{\mathrm{m}}$ but affected $\mathrm{k}_{\mathrm{g}}$ values. The efficiencies of use, $k_{p}$ and $k_{f}$, were similar between the sexes evaluated in this study.

Differences in $\mathrm{NE}_{\mathrm{M}}$ between sexes were consistent with what has been reported by different feeding systems (ARC, 1980; CSIRO, 1990; NRC, 2007), which indicated that intact males have $15 \%$ greater energy requirements than females and castrated males. Our findings indicated that castrated males presented similar $\mathrm{NE}_{\mathrm{M}}$ to intact males compared with females, which is consistent with the body composition values reported by Souza et al. (2017) using animals fed ad libitum that were included in the data set used in this report. The body protein of intact and castrated males was greater than the body protein of females, and body fat of castrated males was greater than that of intact males and lower than that of females. Similar findings of the differences in body protein and fat between sexes were reported in studies using other ruminants and pigs (Berg and Butterfield, 1976; Seidman et al., 1982; Geay, 1984). The $\mathrm{NE}_{\mathrm{M}}$ for males $(75 \pm 1.76 \mathrm{kcal} /$ $\mathrm{kg}^{0.75}$ of EBW) was similar to the values reported in cattle also using the comparative slaughter technique (75 kcal $/ \mathrm{kg}^{0.75}$ of EBW; Chizzotti et al., 2008). It is well known that net protein deposition is much less efficient than body fat, with net protein deposition estimates from 10 to 40\% (Garret, 1980), and we also verified that it could be strongly associated with the costs of adipose and muscular tissue maintenance. Indeed, this sex-specific difference may be associated with the similarity in body protein composition shared only between castrated and intact males. We also verified that the $\mathrm{ME}_{\mathrm{M}}$ was different between females and males, and our results are consistent with those reported by NRC (2007).

Almeida et al. (2016) evaluated the mature EBW in Saanen goats and reported that females reached maturity at lower EBW (i.e., $26 \mathrm{~kg}$ of EBW) than castrated males (i.e., $34.9 \mathrm{~kg}$ of $\mathrm{EBW}$ ) and intact males (i.e., $42.6 \mathrm{~kg}$ of EBW). Their findings support our results of lower energy requirements for maintenance of growing females compared with growing males at similar EBW because at a given BW females show greater body fat and lesser body protein thus lower maintenance costs than males (Gill et al., 1989). On the other hand, we found that at the same degree of maturity (i.e., 0.2, 0.4, $0.6,0.8,1.0)$ growing dairy goats of different sexes present similar $\mathrm{NE}_{\mathrm{M}}$. Similarly, Souza et al. (2017) reported sex does not influence the net energy requirements for growth estimation of Saanen goats when the degree of 
maturity is considered. The lack of differences in energy requirements for maintenance of males and females using the latter approach is a response to similar body fat and protein amounts in goats at the same degree of maturity. This similarity may also be supported by the identical partial efficiencies of energy retention as fat and as protein in those goats (i.e., 0.2 for protein and 0.8 for fat, irrespective of sex). The visceral organs have a major effect on the energetic expenditure to the maintenance (Baldwin et al., 1985; Ferrell, 1988). Previous report presented that sex does not affect the growth of visceral organs in Saanen goats (Andrade, 2017).

In the present study, we estimated the $\mathrm{NE}_{\mathrm{M}}$ considering the degree of maturity based on the ratio EBW/ mature EBW. Our findings are consisted with the results reported by Freetly et al. (2002) studying sheep, where there was a decline in HP with maturity. This decline represents a decrease in the metabolic rate with maturity also reported in other studies (Blaxter, 1962; Freetly et al., 1995).

The $\mathrm{ME}_{\mathrm{M}}$ in Saanen goats was also calculated using the feeding trial methodology. The estimates obtained using the comparative slaughter technique differed between males (with a CI between 115.7 to $125.5 \mathrm{kcal} /$ $\mathrm{kg}^{0.75}$ of EBW) and females (with a CI between 92.3 to $108.8 \mathrm{kcal} / \mathrm{kg}^{0.75}$ of EBW). On the other hand, the estimates from feeding trials ranged from 119.5 to 131.2 $\mathrm{kcal} / \mathrm{kg}^{0.75}$ of EBW, but they did not differ between sexes. Hence, the values from feeding trials were slightly closer to the estimates obtained from males using the comparative slaughter technique; however, we clearly show that significant variation is present in the data from feeding trials that could mask differences between the sexes. The $\mathrm{ME}_{\mathrm{M}}$ for males (in units of $\mathrm{BW}$ ) from the comparative slaughter technique was also lower than that reported from current feeding systems; the value of the present study (102 kcal $/ \mathrm{kg}^{0.75}$ of BW) was similar to the $\mathrm{ME}_{\mathrm{M}}$ reported by Salah et al. $(2014 ; 105$ $\mathrm{kcal} / \mathrm{kg}^{0.75}$ of $\left.\mathrm{BW}\right)$, but lower than the $\mathrm{ME}_{\mathrm{M}}$ reported by NRC (2007) and AFRC (1998), which were 128 and $117 \mathrm{kcal} / \mathrm{kg}^{0.75}$ of BW, respectively. When we evaluated the variance of the errors between models, we found that the nonlinear model obtained using HP and MEI was more precise than the linear model based on the MEI and EWG. This may explain why we did not detect differences between sexes using the linear model based on MEI and EWG.

Using the approach of feeding trials, we also reported the value for $\mathrm{ME}_{\mathrm{G}}$ of $12.5 \mathrm{kcal} / \mathrm{g}$ of $\mathrm{ADG}$ and $15.0 \mathrm{kcal} / \mathrm{g}$ of EWG, which were calculated from the slopes of the linear regression between MEI and ADG, and between MEI and EWG, respectively. These values were greater than those previously reported (NRC, 2007; $5.52 \mathrm{kcal} / \mathrm{g}$ of ADG) that also did not report differences between sexes. When we evaluated $k_{g}$ differences between sexes in Saanen goats, we found values for castrated males, intact males, and females were $0.32,0.26$, and 0.31 , respectively. Using the values for $\mathrm{ME}_{\mathrm{G}}$ and $\mathrm{k}_{\mathrm{g}}$, the $\mathrm{NE}_{\mathrm{G}}$ was predicted to be $4.0,3.25$, and $3.87 \mathrm{kcal} / \mathrm{g}$ of ADG or $4.8,3.9$, and $4.65 \mathrm{kcal} / \mathrm{g}$ of EWG for castrated males, intact males, and females, respectively. These values for $\mathrm{NE}_{\mathrm{G}}$ were greater than the values reported by Souza et al. (2017), which were based on the comparative slaughter technique and reported values of 1.74 to 3.75 $\mathrm{kcal} / \mathrm{g}$ of EWG for castrated males, 1.73 to $2.89 \mathrm{kcal} / \mathrm{g}$ of EWG for intact males, and 1.86 to $4.77 \mathrm{kcal} / \mathrm{g}$ of EWG for females. Both approaches are consistent with intact males having lower $\mathrm{NE}_{\mathrm{G}}$ due to lower fat deposition than castrated males and females, but the values obtained using the comparative slaughter technique provided lower values overall. The $\mathrm{NE}_{\mathrm{G}}$ values in the present study were similar to $\mathrm{NE}_{\mathrm{G}}$ reported by AFRC (1998), which were 2.2 to $4.1 \mathrm{kcal} / \mathrm{g}$ of EWG and obtained from experiments that used the comparative slaughter technique.

The uncertainty verified for the $\mathrm{k}_{\mathrm{m}}$ was lower than that for $\mathrm{k}_{\mathrm{g}}$. The $\mathrm{k}_{\mathrm{m}}$ is by definition related to fasting HP (Garret, 1980), and the estimates in the present study (0.61-0.64) were consistent with $\mathrm{k}_{\mathrm{m}}$ reported by Nie et al. (2015) in lambs (0.64-0.65) and in beef cattle (0.67; Chizzotti et al., 2008), which also did not find an effect of sex on $\mathrm{k}_{\mathrm{m}}$.

Diet effects on $\mathrm{k}_{\mathrm{m}}$ have been reported (ARC, 1980), and the ARC reports propose an approach to calculate $\mathrm{k}_{\mathrm{m}}$ using the $q$ of diet using the following equation: $\mathrm{k}_{\mathrm{m}}$ $=0.30 \times q+0.546$. Applying this approach and using the $q$ obtained for animals fed at the maintenance level in the present study (0.61), we calculated an estimated $\mathrm{k}_{\mathrm{m}}$ of 0.73 . Using this equation can therefore underestimate $\mathrm{ME}_{\mathrm{M}}$. Differences in $\mathrm{k}_{\mathrm{m}}$ that were related to diet were associated with extra heat and differences in time required to chew feed (Susenbeth et al., 1998; Salah et al., 2014); however, the results presented by Galvani et al. (2014) that evaluated low-quality and mediumquality diets concluded that $\mathrm{k}_{\mathrm{m}}$ was not affected by the energy concentration of the diet. The results of $\mathrm{k}_{\mathrm{m}}$ we report here were also not affected by the different body composition of the goat sexes.

The differences in $\mathrm{k}_{\mathrm{g}}(0.32,0.26$, and 0.31 , for castrated males, intact males, and females, respectively) are related to the differences in body composition between males and females, since $\mathrm{k}_{\mathrm{g}}$ represents energy utilization for the deposition of protein and fat in the body. Although Ferrell (2003) discussed the effect of body composition on $\mathrm{k}_{\mathrm{g}}$, the most common feeding systems for goats (AFRC, 1998; CSIRO, 2007; NRC, 2007) have ignored the effects of gain composition on $\mathrm{k}_{\mathrm{g}}$, which 
is predicted based on the characteristics of the diet. In general, these models overestimated the values of $\mathrm{k}_{\mathrm{g}}$ reported in the present study. On the other hand, Tedeschi et al. (2004) proposed a more mechanistic way of estimating $\mathrm{k}_{\mathrm{g}}$ based on the $\mathrm{RE}_{\mathrm{p}}\left[\mathrm{k}_{\mathrm{g}}=3 /(4+11\right.$ $\left.\times \mathrm{RE}_{\mathrm{p}}\right)$ ]. This relationship was developed for growing cattle assuming an average efficiency of fat and protein deposition of 75 and $20 \%$, respectively. This equation was modified for sheep by Cannas et al. (2006) and later adopted by the Small Ruminants System (SRNS), assuming average efficiency of fat and protein deposition of 68 and $27 \%$, respectively $\left[\mathrm{k}_{\mathrm{g}}=18.36 /(27+41 \times\right.$ $\left.\left.\mathrm{RE}_{\mathrm{p}}\right)\right]$. In the present study we also showed that protein is less efficient to be deposited than fat $\left(k_{p} 0.21\right.$ and $\mathrm{k}_{\mathrm{f}}$ 0.80). The $\mathrm{RE}_{\mathrm{p}}$ for growing animals reported herein ranged from 0.07 to 0.66 , which results in $\mathrm{k}_{\mathrm{g}}$ ranging from 0.27 to 0.63 using the equation proposed by Tedeschi et al. (2004) and ranging from 0.34 to 0.42 using the equation proposed by Cannas et al. (2006).

The results from the partitioning of $\mathrm{k}_{\mathrm{p}}$ and $\mathrm{k}_{\mathrm{f}}$ showed that these efficiencies were not affected by sex. Although the values of $\mathrm{k}_{\mathrm{p}}$ and $\mathrm{k}_{\mathrm{f}}$ were similar between the sexes, the proportion of protein and fat deposited in the body were different, indicating that $\mathrm{k}_{\mathrm{g}}$ was affected as a response to different proportions of protein and fat in the body. In the present study, our evaluation of confidence intervals indicated a large uncertainty of the $\mathrm{k}_{\mathrm{f}}$, which represented a large individual uncertainty of the fat deposition in each animal. The deposition of protein was more precise than fat deposition, which was reflected in the lower uncertainty. The reported $k_{p}$ $(0.20)$ and $\mathrm{k}_{\mathrm{f}}(0.75)$ in cattle (Geay, 1984) were close to the values reported by the present study.

The $\mathrm{k}_{\mathrm{g}}$ estimates we report were different between the Saanen goat sexes $(0.32,0.26$, and 0.31 for castrated males, intact males, and females, respectively), where the lowest $\mathrm{k}_{\mathrm{g}}$ was reported in intact males possibly because they have the lowest proportion of retained fat and highest proportion of retained protein among the sexes tested. Conversely, previous studies evaluating sex effects on $\mathrm{k}_{\mathrm{g}}$ in other ruminants did not report sex effects, suggesting common $\mathrm{k}_{\mathrm{g}}$ values of 0.43 and 0.44 for male and female beef cattle and sheep, respectively (Chizzotti et al., 2008; Nie et al., 2015).

The estimates of net energy requirements provide a more precise quantification of the values because we avoid interference caused by different efficiencies. Body composition did not affect the efficiency of ME utilization for maintenance but did affect the partial energy efficiency for gain, where castrated males and females are more energetically efficient than intact males. To our knowledge, this is the first study that quantifies the energy requirements related to efficiency of energy utilization in Saanen goats over a wide range of BW.
Future studies should focus on evaluating the body composition of mature goats, and describe a general model across sexes based on the degree of maturity. Thus, the information presented by the present study could improve our knowledge about energy partition and support the development of potential strategies to enhance energy utilization informed by the diets of Saanen goats.

\section{CONCLUSIONS}

Sex affects the energy requirements for maintenance and the efficiency of energy use in Saanen goats. Both the $\mathrm{NE}_{\mathrm{M}}$ and $\mathrm{ME}_{\mathrm{M}}$ estimated by the comparative slaughter technique were greater in males than in females. However, sex no longer affected $\mathrm{NE}_{\mathrm{M}}$ when degree of maturity was considered in its estimation. Different sexes of Saanen goats have different $k_{\mathrm{g}}$, but similar $\mathrm{k}_{\mathrm{p}}, \mathrm{k}_{\mathrm{f}}$, and $\mathrm{k}_{\mathrm{m}}$.

\section{ACKNOWLEDGMENTS}

The authors thank the Sao Paulo Research Foundation (FAPESP, Grant \#2014/14734-9, Brazil), and Conselho Nacional de Desenvolvimento Científico e Tecnológico (CNPq, Brazil) for financial support. This work was also financed in part by The Coordenação de Aperfeiçoamento de Pessoal de Nível Superior-Brasil (CAPES)-finance code 001.

\section{REFERENCES}

AFRC. 1998. The Nutrition of Goats. CAB Int., New York, NY.

Almeida, A. K., K. T. Resende, N. St-Pierre, S. P. Silva, D. C. Soares, M. H. M. R. Fernandes, A. P. Souza, N. C. D. Silva, A. R. C. Lima, and I. A. M. A. Teixeira. 2015. Energy requirements for growth in male and female Saanen goats. J. Anim. Sci. 93:3932-3940.

Almeida, A. K., K. T. Resende, L. O. Tedeschi, M. H. M. R. Fernandes, J. G. L. Regadas Filho, and I. A. M. A. Teixeira. 2016. Using body composition to determine weight at maturity of male and female Saanen goats. J. Anim. Sci. 94:2564-2571.

Andrade, M. E. B. 2017. Growth curves of the visceral organs of Saanen goats. Master's Thesis. Department of Animal Sciences, Sao Paulo State University, São Paulo, Brazil.

AOAC. 1990. Official methods of analysis. 15th ed. Assoc. Off. Anal. Chem., Arlington, VA.

ARC. 1980. The nutrient requirements of ruminant livestock. Commonw. Agric. Bur., Slough, UK.

Ash, A. J., and B. W. Norton. 1987. Studies with the Australian cashmere goat. II. Effects of dietary protein concentration and feeding level on body composition of male and female goats. Crop Pasture Sci. 38:971-982.

Baldwin, B. R., N. E. Forsberg, and C. Y. Hu. 1985. Potential for altering energy partition in the lactating cow. J. Dairy Sci. 68:33943402.

Berg, R. T., and R. M. Butterfield. 1976. New Concepts of Cattle Growth. Macarthur Press. Sydney, Australia.

Blaxter, K. L. 1962. The fasting metabolism of adult wether sheep. Br. J. Nutr. 16:615-626.

Blaxter, K. L., and J. L. Clapperton. 1965. Prediction of amount of methane produced by ruminants. Br. J. Nutr. 19:511-522. 
Bompadre, T. F., O. B. Neto, A. N. Mendonca, S. F. Souza, D. Oliveira, M. H. M. R. Fernandes, C. J. Harter, A. K. Almeida, K. T. Resende, and I. A. M. A. Teixeira. 2014. Energy requirements in early life are similar for male and female goat kids. Asian-Australas. J. Anim. Sci. 27:1712-1720.

Cannas, A., L. O. Tedeschi, A. S. Atzori, and D. G. Fox. 2006. Prediction of energy requirement for growing sheep with the Cornell Net Carbohydrate and Protein System. Pages 99-113 in Nutrient Digestion and Utilization in Farm Animals: Modelling Approaches. E. Kebreab, J. Dijkstra, A. Bannink, W. J. J. Gerrits, and J. France, ed. CAB International, Wallingford, UK.

Chizzotti, M. L., L. O. Tedeschi, and S. C. Valadares Filho. 2008. A meta-analysis of energy and protein requirements for maintenance and growth of Nellore cattle. J. Anim. Sci. 86:1588-1597.

CSIRO. 1990. Feeding standards for Australian livestock: Ruminants. CSIRO Publ., Melbourne, Australia.

CSIRO. 2007. Nutrient Requirements of Domesticated Ruminants. CSIRO Publ., Collingwood, Australia.

Etheridge, R. D., G. M. Pesti, and E. H. Foster. 1998. A comparison of nitrogen values obtained utilizing the Kjeldahl nitrogen and Dumas combustion methodologies (Leco CNS 2000) on samples typical of an animal nutrition analytical laboratory. Anim. Feed Sci. Technol. 73:21-28.

Fan, X., A. Felsovalyi, S. A. Sivo, and S. C. Keenan. 2002. SAS for Monte Carlo Studies: A Guide for Quantitative Researchers. SAS Inst. Inc., Cary, NC.

Ferreira, A. C. D., E. A. Yáñez, A. N. Medeiros, K. T. Resende, J. M. Pereira Filho, M. H. M. R. Fernandes, A. K. Almeida, and I. A. M. A. Teixeira. 2015. Protein and energy requirements of castrated male Saanen goats. Small Rumin. Res. 123:88-94.

Ferrell, C. L. 1988. Contribution of visceral organs to animal energy expenditure. J. Anim. Sci. 66:23-34.

Ferrell, C. L. 2003. Energy partitioning in ruminants as related to feed intake. In Conference Proceedings of the Canadian Society of Animal Science. Can. Soc. Anim. Sci., Saskatoon, Canada.

Figueiredo, F. O. M., T. T. Berchielli, K. T. Resende, H. F. B. Gomes, A. K. Almeida, N. K. Sakomura, and I. A. M. A. Teixeira. 2016. Energy requirements for growth of pubertal female Saanen goats. J. Anim. Physiol. Anim. Nutr. (Berl.) 100:294-300.

Figueiredo, F. O. M., R. F. Leite, N. R. St-Pierre, K. T. Resende, A. K. Almeida, A. P. Souza, and I. A. M. A. Teixeira. 2017. Energy and protein requirements of weaned male and female Saanen goats. J. Anim. Physiol. Anim. Nutr. (Berl.) 101:1014-1025.

Freetly, H. C., J. A. Nienaber, and T. Brown-Brand. 2002. Relationships among heat production, body weight, and age in Finnsheep and Rambouillet ewes. J. Anim. Sci. 80:825-832.

Freetly, H. C., J. A. Nienaber, K. A. Leymaster, and T. G. Jenkins. 1995. Relationships among heat production, body weight, and age in Suffolk and Texel ewes. J. Anim. Sci. 73:1030-1037.

Galvani, D. B., A. V. Pires, I. Susin, V. N. Gouvêa, A. Berndt, L. J. Chagas, J. R. R. Dórea, A. L. Abdalla, and L. O. Tedeschi. 2014. Energy efficiency of growing ram lambs fed concentrate-based diets with different roughage sources. J. Anim. Sci. 92:250-263.

Garret, W. N. 1980. Factors influencing energetic efficiency of beef production. J. Anim. Sci. 51:1434-1440.
Geay, Y. 1984. Energy and protein utilization in growing cattle. J. Anim. Sci. 58:766-778.

Gill, M., J. France, M. Summers, B. W. McBride, and L. P. Milligan. 1989. Simulation of the energy costs associated with protein turnover and $\mathrm{Na}^{+}, \mathrm{K}^{+}$-transport in growing lambs. J. Nutr. 119:1287-1299.

Gomes, H. F. B. 2011. Composição corporal e exigências nutricionais de caprinos Saanen machos dos 30 aos $45 \mathrm{~kg}$. MS Thesis. Department of Animal Sciences, Sao Paulo State University, Sao Paulo, Brazil.

Herring, M. J., P. M. Oskui, S. L. Hale, and R. A. Kloner. 2013. Testosterone and the cardiovascular system: A comprehensive review of the basic science. J. Am. Heart Assoc. 2:e000271.

Lofgreen, G. P., and W. N. Garrett. 1968. A system for expressing net energy requirements and feed values for growing and finishing beef cattle. J. Anim. Sci. 27:793-806.

Luo, J., A. L. Goetsch, T. Sahlu, I. V. Nsahlai, Z. B. Johnson, J. E. Moore, M. L. Galyean, F. N. Owens, and C. L. Ferrell. 2004. Prediction of metabolizable energy requirements for maintenance and gain of pre-weaning, growing and mature goats. Small Rumin. Res. 53:231-252.

Medeiros, A. N., K. T. Resende, I. A. M. A. Teixeira, M. J. Araújo, E. A. Yáñez, and A. C. D. Ferreira. 2014. Energy requirements for maintenance and growth of male Saanen goat kids. Asian-Australas. J. Anim. Sci. 27:1293-1302.

Nie, H. T., J. H. You, H. Zhang, and F. Wang. 2015. Determination of energy and protein requirement for maintenance and growth and evaluation for the effects of gender upon nutrient requirement in Dorper $\times \mathrm{Hu}$ crossbred lambs. Trop. Anim. Health Prod. $47: 841-853$

NRC. 2000. Nutrient requirements of beef cattle. 7th rev. ed. Natl Acad. Press, Washington, DC.

NRC. 2007. Nutrient requirements of small ruminants: Sheep, goats, cervids, and new world camelids. 1st rev. ed. Natl. Acad. Press, Washington, DC.

Sahlu, T., A. L. Goetsch, J. Luo, I. V. Nsahlai, J. E. Moore, M. L. Galyean, F. N. Owens, C. L. Ferrel, and Z. B. Johnson. 2004. Nutrient requirements of goats: Developed equations, other considerations and future research to improve them. Small Rumin. Res. 53:191-219.

Salah, N., D. Sauvant, and H. Archimède. 2014. Nutritional requirements of sheep, goats and cattle in warm climates: A meta-analysis. Animal 8:1439-1447.

Seidman, S. C., H. R. Cross, R. R. Oltjen, and B. D. Schanbaher. 1982. Utilization of the intact male for red meat production: A review. J. Anim. Sci. 55:826-840.

Souza, A. P., N. R. St-Pierre, M. H. R. M. Fernandes, A. K. Almeida, J. A. C. Vargas, K. T. Resende, and I. A. M. A. Teixeira. 2017. Sex effects on net protein and energy requirements for growth of Saanen goats. J. Dairy Sci. 100:4574-4586.

Susenbeth, A., R. Mayer, B. Koehler, and O. Neumann. 1998. Energy requirement for eating in cattle. J. Anim. Sci. 76:2701-2705.

Tedeschi, L. O., D. G. Fox, and P. J. Guiroy. 2004. A decision support system to improve individual cattle management. 1. A mechanistic, dynamic model for animal growth. Agric. Syst. 79:171-204. 